American Journal of Environmental Sciences 5 (1): 16-32, 2009

ISSN $1553-345 \mathrm{X}$

(C) 2009 Science Publications

\title{
Physical and Biological Responses of Forests to Tropical Cyclones Affecting the United States Atlantic Ocean and Gulf of Mexico Coasts
}

\author{
Krista Merry, Pete Bettinger and Jeffrey Hepinstall \\ Warnell School of Forestry and Natural Resources, University of Georgia, Athens, GA 30602, USA
}

\begin{abstract}
Problem Statement: Natural resources within the southern United States have repeatedly been subjected to the impact of tropical cyclones. While the frequency of tropical cyclones hitting either coast varies from year to year, it is crucial for natural resource managers and land owners to be prepared for the damage resulting from such storms. The goal of this review paper is to synthesize previous research and assess how hurricanes impact coastal forests. Approach: In order to understand the impact on forests in this region, an extensive literature review was preformed. The literature review focused primarily on the southern United States' forests but included information from other areas that was pertinent in understanding the impact of strong wind events on forests. Results: Although the literature is not entirely consistent in arriving at factors that can be used to describe or predict potential damage to forests, a number of trends were obvious. Forest damage was found to be a function of tree species, proximity to the eye of the hurricane, stand and site characteristics, species-specific responses to storm surges, and topographic exposure. Each of these factors was found to be critical in developing and understanding potential hurricane damage to forest and wildlife values. Conclusions/Recommendations: Such a review paper was found to be a valuable tool for informing natural resource managers and forest land owners of the potential impacts of hurricanes on the forest of the southern United States. This information will help land managers develop a response plan related to hurricane damage.
\end{abstract}

Key words: Tropical cyclones, wind damage, storm surge damage, forest characteristics

\section{INTRODUCTION}

Along the United States coastlines, tropical cyclones (hurricanes) are imminent and come with potentially dire consequences for both the human and natural environment. It has been hypothesized that hurricanes have replaced fire as the natural disturbance of the southern U.S., creating conditions necessary for natural stand establishment and stand maintenance for certain species such as slash pine(Pinus elliotti $)^{[25,100]}$. Determining the historic frequencies, location and impact of a hurricane is difficult at best. Hurricane activity can range annually from frequent (i.e., 2005) to infrequent (i.e., 2007) but generally there are about five hurricanes per year in the North Atlantic. Hurricane activity in the Atlantic Ocean is generally thought to have increased since 1995 and is projected to perhaps remain at increased levels for the next 4 decades due to higher sea surface temperatures and decreased wind shear $^{[49]}$.

In general, portions of the United States coastline have had limited experience with major hurricane damage, but with the expected increase in hurricane activity there is a higher potential for hurricane destruction than in previous periods of time. While some areas may have been affected by hurricanes repeatedly over a relatively short period of time, others have experienced minimal hurricane activity. For example, the Outer Banks area of North Carolina was hit by six named storms (Bertha, Fran, Bonnie, Dennis, Floyd and Irene) between 1996 and 1999, with three occurring in $1999^{[70]}$. Conversely, Savannah, Georgia has an estimated return period for a major hurricane directly striking every 34 years, however, the last direct hit on Savannah occurred 150 years ago. Additionally, any category of storm is estimated to directly strike Savannah every 8 years, however, the last one to do so occurred 30 years ago.

A Category 5 hurricane on the Saffir-Simpson scale can be expected in the Atlantic basin about once every 2.3 years $^{[92]}$. A Category 4 or stronger hurricane hits the United States, on average, every 7 years ${ }^{[10]}$. This expected frequency combined with increased populations in coastal areas could lead to economic devastation if a powerful storm hits the Atlantic coast $^{[49]}$. Identifying specific locations that will be

Corresponding Author: Krista Merry, Warnell School of Forestry and Natural Resources, University of Georgia, Athens, GA 30602 , USA Tel: 706-542-4928 Fax: 706-542-8356 
heavily impacted by storms during a hurricane season is virtually impossible until a storm is developing or threatening. While the likelihood of damage to humans and infrastructure can be minimized through response plans, evacuation procedures and recovery efforts, forests and other natural resources may bear the brunt of the damage due to their fixed locations and a potential lack of preparedness by the natural resource management community. Therefore, focus needs to be directed toward understanding the potential impacts of hurricanes and tropical storms on natural resources to prepare land managers for the aftermath of a major hurricane.

Areas that are hit directly by a storm characteristically incur the most damage. A direct hit on land is defined as the land area within the radius of maximum winds of a hurricane. The direct hit zone varies from one storm to the next, however and may extend as wide as $160 \mathrm{~km}$ for major storms ${ }^{[42]}$. Blake et $a l .{ }^{[10]}$ suggested that a direct hit zone could extend approximately $70 \mathrm{~km}$ from the eye, specifically, extending approximately $25 \mathrm{~km}$ to the left of the forward path and $45 \mathrm{~km}$ to the right of the forward path. In some instances, hurricanes have the potential to reach a radius of approximately $1,000 \mathrm{~km}$, extending the size of the direct hit zone ${ }^{[42]}$.

Characteristically, the eye of a storm is described as the center with low intensity and pressure. The surrounding $30 \mathrm{~km}$ is defined as the eyewall and is the portion of the storm with the highest velocity winds and most often with the heaviest precipitation ${ }^{[42]}$. Early study by Jordan et al. ${ }^{[64]}$, however, suggested that the strongest wind speeds were found at about the same distance from the eye in all directions. Maximum winds at low-level elevations are found near the eye wall, in the right-front quadrant relative to the direction of travel. The maximum wind speed associated with Hurricane Andrew (1992), for example, was about $77 \mathrm{~m}$ $\mathrm{sec}^{-1[73]}$, in the northern eyewall. Generally, there is an inverse correlation between maximum wind speed and the distance from a hurricane's eye, except for areas within the radius of maximum winds ${ }^{[57]}$. Frequently, the greatest damage is incurred near the track of the eye of the storm ${ }^{[68,105]}$. The strongest damage to forests and other landscape features occurs on the side of the eyewall where translational and rotational effects are in the same direction ${ }^{[105]}$ specifically, the northern rightfront quadrant of the storm ${ }^{[32,73,94,99]}$. Further, a higher severity of damage is correlated with longer durations of sustained wind speeds ${ }^{[91]}$. Hurricanes typically loose strength as they pass over land due to a decrease in convection $^{[73]}$.

Although rain is generally heaviest within the eye wall cloud, the strongest electrical activity (lightning) and turbulence can be experienced in the individual cloud cells in the outer bands of the hurricane ${ }^{[64]}$. Tornadoes, for example, can occur approximately 80$320 \mathrm{~km}$ away from the hurricane eye, outside of the area of known hurricane-force winds. Typically, tornadoes occur in the northeast and east quadrants (30$120^{\circ}$ ) regardless of the direction of the hurricane path $^{[1,80,82]}$. Tornadoes can potentially precede hurricane force winds beginning up to $12 \mathrm{~h}$ prior to the arrival of the main body of the storm ${ }^{[82]}$. During Hurricane Beulah (1967), tornadoes occurred mostly $160-320 \mathrm{~km}$ away from the hurricane eye in the northeast quadrant of the storm ${ }^{[80]}$.

Estimating the level of damage following a hurricane as well as preparing in advance for disaster recovery is complicated by the number of variables associated with storm damage. Forests may be subjected to winds and storm surges and in some instances heavy rains. The variable characteristics of storms make predicting damage difficult, at best. The purpose of this review paper is to provide insight into potential damage to forests resulting from hurricanes along the Atlantic Ocean and Gulf of Mexico in the United States. The review represents a synopsis of the available literature and is meant to provide resource managers and landowners with information to aid in preparing for and managing the response following a hurricane. In describing the biological responses of forests to hurricanes, we summarize several topics including: the effects of wind on forests and individual trees, how tree physiology may determine damage, how specific tree species respond, the relationship between stand and site conditions and hurricane damage, the relationship between topography and hurricane damage, the impact of storm surges, the levels of tree mortality and the impacts on tree regeneration, and the potential impact on wildlife.

\section{METHODS AND MATERIALS}

In order to gain insight into the impact of hurricanes on forest, a thorough and extensive literature review was conducted. This literature review included peerreviewed journal articles, books, government agency publications, conference proceedings, and technical reports. The literature was limited to those that could provide insight into the strength, behavior, and impact of hurricanes on forest similar to those found in the southern United States. In a few cases, such as Fraser ${ }^{[43]}$ and $\mathrm{Kramer}^{[65]}$, literature describing the impacts of strong winds on trees or other resources was consulted because they represented the only work of 
their kind. In total, 253 articles were obtained and reviewed.

\section{RESULTS}

Tree damage and winds: Damage to forests and natural resources during a hurricane will occur primarily as a result of winds and storm surges generated by the storm. To fully understand how forests respond to hurricane force winds, we must understand how trees will react, as individuals as well as in stands, to forces associated with large storms and how site conditions, tree age, tree stocking, tree species and other factors influence levels of damage. Forest damage may be most closely related to gusts of wind or a single, very strong wind event lasting only a few seconds, as opposed to maximum sustained wind speeds. For example, the majority of damage following Hurricane Fran (1993) was attributed to wind gusts ${ }^{[108]}$. Gusts most commonly occur vertically within approximately $500 \mathrm{~m}$ of the ground ${ }^{[41]}$. Wind gusts producing damage inland could arise from convective transfer of momentum downward, causing winds from the level of strongest wind speed (approx. 150-500 m elevation) to be transported downward to the ground. Gusts are sporadic and are associated with increased wind speeds affecting small areas. In addition, there is a resonance effect when the gust frequency is in phase with the sway of a tree, transferring greater energy to $\mathrm{it}^{[9]}$. Most often, trees closest to the gust path will incur the greatest amount of damage with intensity diminishing as a function of distance from the path of the gust ${ }^{[45]}$. Vertical and horizontal gusts combine to form sweeps. Sweeps, characteristically, are fast moving winds in a downward motion through a forest canopy ${ }^{[39]}$ and have been positively correlated with the direction of the wind at the ground surface ${ }^{[87]}$.

During a wind storm, the tip of a tree oscillates in an elliptical manner, with the major axis pointing in the general direction of the wind ${ }^{[74]}$. Trees sway elliptically because of abnormalities on crowns, asymmetrical root systems, irregular tree stem shape, wood elasticity and friction between the wind and the crown ${ }^{[72]}$. As a result, all sides of a tree stem and its root system are stressed during this rotational process. Both the stem and the root system are affected by wind, with the windward side of the tree under tension and the leeward side under compression. The swinging motion of a tree during a wind event can bend stems to the point where compression strength of the wood is exceeded (leading to breakage). Compression strength is about one-third of the tension strength of wood ${ }^{[74]}$. Mayer ${ }^{[72]}$ suggested that no tree species can survive storms with wind speeds greater than $30 \mathrm{~m} \mathrm{sec}^{-1}$ for more than $10 \mathrm{~min}$.
Canopy gaps resulting from the death of a tree or from management practices can be the starting point for wind damage. When an opening occurs, wind enters and expands its force on those trees around the gap. Wind acting on a tree produces a bending force, which is concentrated at the form point, which is one-third of the distance from the base of the crown to the top of the crown. The lower the form point, the lower the probability of damage. Longer crowns imply a lower center of gravity, therefore, trees with longer crowns, or lower form points, will be more wind resistant ${ }^{[30,18]}$. Conversely, tall, slender trees with small crowns (10$20 \%$ of the height of the tree) have also been found to be relatively wind resistant with the stem absorbing most of the force ${ }^{[30]}$.

Resistive forces of trees include stem stiffness, the support given by other trees and root anchorage. When the applied bending moment on a tree exceeds the maximum resistive bending moment for the tree (stem or roots), it breaks or is windthrown ${ }^{[72]}$. Trees break when subjected to lateral forces that exceed the stem strength, but do not exceed the ability of the root system to become dislodged from the soil ${ }^{[74]}$. It has been hypothesized that wider, less dense annual tree rings in second-growth trees may make the tree more vulnerable to damage ${ }^{[86]}$. Further, Petty and Swaii ${ }^{[84]}$ identified the role of tree taper in wind damage susceptibility. Trees with higher taper are more stable at certain winds speeds than other trees of lower taper $^{[9,72,84]}$. This implies that the higher height/diameter ratio trees are more susceptible to windthrow at various wind speeds than lower height/diameter ratio trees (which have high higher taper values). The relationship between height/diameter values and the wind speed necessary to cause breakage is non-linear and based on the relationship between crown weight and stem weight, suggesting that tree taper is probably the most important factor influencing the susceptibility to breakage ${ }^{[60]}$.

Windthrow, or uprooting, suggests that a tree has fallen with most of its roots intact. Windthrow occurs when the lateral forces applied to a tree overcome the root anchorage ${ }^{[89,95]}$. In this case, the stem does not generally break and the soil mass adhering to the roots is generally attached, resulting in pit-mound microtopography ${ }^{[86]}$. The drag coefficient of a tree canopy is important in determining the type of wind damage, as is the canopy position, the water balance and nutrient regime of the tree, the age of the tree and the species ${ }^{[95]}$. The roots that strengthen trees against wind are short, stout, horizontal or oblique roots of the bracket-angle type. The anchoring ability of a tree may depend on the strength of these roots on the leeward side of the tree. In every case of windthrow, these roots failed by compression on the leeward side of the tree. 
The essential roots are the bracket roots on the lee side of the tree (given a predominant wind direction) ${ }^{[60]}$. The physical conditions of the soil and the depth and extent of tree rooting factor into whether windthrow will occur, except in extreme storms ${ }^{[43]}$. Additionally, shallow rooting, moist soil conditions and root rot all contribute to an increased vulnerability to windthrow. In fact, anything that impedes deep rooting of trees makes them more susceptible to windthrow ${ }^{[43,53,95]}$. Root strength of large trees is difficult to determine and varies due to soil type and moisture status. Stem strength is easier to measure and is based on the engineering properties of the species of wood ${ }^{[89]}$. Following Hurricane Flossy (1956) it was found that restricted root development along with highly saturated soils are believed to be primarily responsible for windthrow events. Soils with a clay layer in the top 55 centimeters of soil produced $90 \%$ of the tree windthrow. Soils with deeper clay layers, covering over $50 \%$ of the area, produced only $10 \%$ of observed windthrow ${ }^{[29]}$.

Literature concerning the physical damage threshold for a species is generally lacking. These values are a function of wind speed, wind duration, terrain features, soil type, stand characteristics and the physical condition of the tree. However, in general, tree species with taproots that extend deep into the soil are more likely to break than to be windthrown. If the soil is frozen or very dry, stem breakage will likely occur rather than windthrow. And, higher moisture contents of soils will likely lead to increased windthrow ${ }^{[72]}$. Conversely, Jacobs ${ }^{[60]}$ found that the taproot of most species is of minor mechanical value, especially on larger trees, however on certain soil types, the taproot may increase the windfirmness of individual trees.

The resistance of a soil to pressure, thrust and pull varies with soil texture, organic matter and moisture content ${ }^{[74]}$. In addition, the strength of the roots of a tree to hold itself stable against wind is dependent on the sheer strength of the soil, which is dependent on soil moisture content ${ }^{[18]}$. Non-cohesive soils, such as sandy soils, anchor trees through frictional processes only and are better at helping trees resist windthrow when the moisture content is near field capacity. Cohesive soils, such as clayey soils, are better at helping trees resist windthrow when soils are dry (highest cohesion) ${ }^{[74]}$. Silt and clay soils lose their cohesion and become plastic in the presence of large amounts of water. When a soil is saturated, it loses its plastic property and becomes fluid. It then has little to no shearing strength and is readily deformed. Trousdell et al. ${ }^{[103]}$ found that greater wind damage occurred from Hurricane Donna (1960) on soils with restricted layers in the soil profile (i.e., clay). Half of the trees on these soil types were damaged, while only $7 \%$ of trees on other soil types were damaged.
Greater wind damage was also observed on soils with moderately course texture with $30 \%$ of trees damaged, whereas only $5 \%$ were damaged on other soil textures. The wind damage combined with heavy rains prior to the storm accounted for the resulting forest damage.

Heavy rains that may precede hurricanes increase the susceptibility of uprooting ${ }^{[95]}$, however, not all hurricanes bring with them heavy rains ${ }^{[85]}$. Windthrow in the Duke Forest (North Carolina) following Hurricane Fran (1996) was closely associated with the rainfall accompanying the storm ${ }^{[108]}$. Soil substrate (e.g., sand) can also influence windthrow potential ${ }^{[32]}$. However, the vulnerability to windthrow may be related to some unmeasured architectural or morphological feature of trees, such as wood strength, therefore specific wind and site characteristics may also play a role in windthrow potential ${ }^{[50]}$. Drainage of the soil is essential, since as we suggested, a tree's grip on the soil is lessened when the soil becomes saturated ${ }^{[18]}$. In contrast, if a soil is frozen or very dry, stem breakage, rather than windthrow, will likely occur ${ }^{[72]}$.

In addition to breakage and windthrow, wind damage can come in the form of defoliation. Moss ${ }^{[76]}$ found that forests in eastern Connecticut incurred the brunt of the 1938 New England hurricane resulting in severe defoliation. Leaves were stripped from the trees with such force that it left the midribs of hardwood leaves intact and stained white houses a yellow-green color on the windward side. Within approximately 8-15 $\mathrm{km}$ of the coast, foliage of some trees was $100 \%$ damaged. Damage was species-specific, however with white pine (Pinus strobus) incurring severe damage, while Austrian (Pinus nigra), pitch (Pinus rigida) and red pines (Pinus resinosa) faired well. For hardwoods, yellow-poplar (Liriodendron tulipifera) and sourwood (Oxydendrum arboreum) were also severely damaged.

Proximity to the eye of the storm: Proximity to the eye of the storm and location of the affected site in relation to the direction of movement of the storm are essential in estimating the direction of treefall and potential damage to forests ${ }^{[2,3,16,58]}$. As previously mentioned, the greatest amount of damage is found in the northeast quadrant of the storm. For example, the 1938 Hurricane that affected the New England area traveled across Connecticut and Massachusetts then north to Vermont. The greatest amount of forest damage occurred on the east side of the hurricane track $^{[40]}$. Extensive research conducted by the U.S. Forest Service in South Carolina forests following Hurricane Hugo found that winds west of the eye created damage over much less of an area than winds east of the northeast directional path. Nearer the eye, trees fell in a variety of directions. However, the eastern and western sides of the eye, trees fell in directions 
reflective of the counter-clockwise movement of the hurrican ${ }^{[88]}$. Using Geographic Information Science (GIS) analysis, it was determined that damage to all stands was greatest near the eyewall, as distances from the eye increased, the degree of forest damage decreased ${ }^{[78]}$.

The direction of tree fall tends to be closely associated with the sustained wind direction, however, the direction of damaging winds changes during the passage of a hurricane, particularly the closer one gets to the eyewall ${ }^{[12]}$. Hurricane Isabel (2003) made landfall in North Carolina and traveled northwest through Maryland. The eye passed to the west of a research site in the Maryland Piedmont bringing with it relatively slow wind gust speeds (approximately $22 \mathrm{~m} \mathrm{sec}^{-1}$ ). Locations $40 \mathrm{~m}$ inland experienced windthrow in a predominantly westerly direction between $225^{\circ}$ and $315^{\circ}$. About $15.5 \%$ of the trees were windthrown, $4.2 \%$ were snapped off and $3.8 \%$ were leaning as a result of the hurricane. As a result, $23.5 \%$ of the trees were severely damaged and $25 \%$ of the basal area was severely damaged. About $20 \%$ of the area was composed of gaps (largest gap was 0.15 ha). Areas with larger diameter trees had greater probability of windthrow. Areas with a significant percentage of yellow-poplar also had higher probabilities of windthrow ${ }^{[13]}$.

Local conditions can also play a role in areas that are within close proximity to the radius of maximum sustained winds. Windthrow associated with the passage of Hurricane Katrina in 2005, for example, most frequently occurred along roads, powerlines, open fields and other landscape corridors, due to the higher exposure to strong winds ${ }^{[99]}$. Windthrow was also found frequently in forested areas with edges created by adjacent stands with varying tree heights and densities $^{[71]}$. Abrupt changes in tree heights along edges cause wind to be obstructed and as a result, turbulence is created which penetrates into the stand some small distance $^{[18]}$. Grisez ${ }^{[53]}$ observed similar patterns associated with the passage of Hurricane Edna in 1954 in the northeastern U.S., as did Craighead and Gilbert $^{[27]}$ following the passage of Hurricane Donna in 1960 in Florida. Cremer et al. ${ }^{[28]}$ suggest that margins of stands should be thinned and pruned to make them more wind-permeable and therefore prevent extreme turbulence events at the edges of stands.

Satellite imagery can be used to assess the impacts of storms across broad landscapes. Using AVHRR satellite data captured over Puerto Rico prior to and after Hurricane Georges (1998), Normalized Difference Vegetation Index (NDVI) values were used to assess vegetation changes following the $\operatorname{storm}^{[3]}$. The path of the storm transected the island crossing from the southeast to the northwest ends. It was determined that higher risk areas were those within $12 \mathrm{~km}$ from the eye. Through regression analysis, it was determined that negative changes in NDVI were significantly related to proximity of the track of Hurricane Georges. Locations on the southern portion of the island had the largest decreases in NDVI values following the storm.

Stand and Site Conditions in Relation to Damage: It has been suggested that the impact of a hurricane on forested ecosystems is a function of the intensity of the storm, its size and directional path and how vulnerable the stand is as a result of previous disturbance, mechanical practices, stand conditions (i.e., density, age, diameter, height, etc. $)^{[101]}$ as well as soil characteristics and topography ${ }^{[2,43,53,72,95,103]}$. Multiple studies have concluded that the likelihood of damage from winds in southeastern forests is strongly correlated with larger tree diameters ${ }^{[31,35,38,46,50,51,88,97]}$. More specifically, it has been suggested that larger diameter trees are more likely to be windthrown while smaller trees are more likely to snap ${ }^{[69]}$. However, following Hurricane Camille (1969), damage occurred across all tree sizes but the majority of breakage occurred in pine trees with diameters larger than $12 \mathrm{~cm}^{[55]}$. Further, after Hurricane Fran (1996), it was found that damage to smaller trees is often indirect and is the result of disturbed adjacent trees, resulting in the bending and pinning of the smaller trees ${ }^{[108]}$.

Gresham et al. ${ }^{[51]}$ found that following Hurricane Hugo (1989) the more abundant species were less intensely damaged than other, less common species. This was perhaps the result of morphological and anatomical properties such as: buttressed boles (cypress [Taxodium spp.]), swamp tupelo (Nyssa sylvatica var. biflora), deciduous habit (cypress), large taproots, widespread lateral root systems (longleaf pine [Pinus palustris]), or low deliquescent canopy and high wood strength (live oak [Quercus virginiana]). Again, larger diameter trees were more heavily damaged than smaller diameter trees, while smaller stems were lightly damaged or undamaged ${ }^{[47,51]}$. Also, larger trees were more commonly directly damaged while smaller trees were more likely to be indirectly damaged ${ }^{[16]}$. Longleaf pine was the exception to this with the smallest trees suffering the heaviest crown damage whereas undamaged or lightly damaged trees were in the intermediate diameter classes. Research following Hurricane Hugo in Puerto Rico found a moderate correlation with the degree of damage (minor to windthrow) and diameter. In heavily disturbed areas, breakage occurred in about $8 \%$ of the trees and about $15-20 \%$ of the trees were windthrown. This damage was uniform across diameter classes. In less-disturbed areas, breakage occurred in about $2-3 \%$ of the trees and about $3-4 \%$ were windthrown ${ }^{[81]}$. 
Up to this point, we have focused on the impact of hurricanes to rural forested areas. However, impacts on urban forests are just as important. A survey of homeowners in the Miami-Dade region of Florida following Hurricane Andrew (1992) also found that larger trees were more susceptible to windthrow than smaller trees. Additionally, those trees that fell were typically broken at the stem or were windthrown. The average size of windthrown slash pine was $56 \mathrm{~cm}$ in diameter and approximately $20 \mathrm{~m}$ tall. The slash pines that remained standing following the storm were about $50 \mathrm{~cm}$ in diameter and $17 \mathrm{~m}$ tall. Slash pines that were damaged were more typically snapped rather than windthrown ${ }^{[35]}$.

In general, even-aged forest stands are most susceptible to wind damage while uneven-aged stands have shown greater resilience. For example, damage to trees concentrated in homogenous stands following Hurricane Hugo (1989) was attributed to stand density and canopy condition rather than the tree species present ${ }^{[16]}$. In fact, any drastic change to the forest structure as a result of management practices will likely have an impact on a stand's resistance to winds ${ }^{[45]}$. Recently thinned stands, for example, may have a higher likelihood for damage than unthinned stands ${ }^{[83]}$. Following Hurricane Audrey (1957), damage to timber plantations was directly correlated to commercial thinnings implemented a year prior to the storm $^{[77]}$. Following Hurricane Edna (1954), damage assessments found that those stands that had been lightly thinned (reduced volume by 15-35\%) incurred the lightest damage ( 9.1 trees/ha), while stands that had been heavily thinned (reduced volume by $50-90 \%$ ) were the most heavily damaged (12.6 trees/ha) and uncut stands had the least damage with a loss of 7.9 trees $/ \mathrm{ha}^{[53]}$. In assessing the damage from Hurricane Hugo in 1989, Nix et al. ${ }^{[78]}$ suggested stand conditions explained about half of the variation in damage levels. Stands of trees grown at higher stocking rates and then thinned appear to be more likely to sustain hurricane damage compared to stands grown at lower stocking rates ${ }^{[48,101]}$. Trees grown closely together often form stable stands as a result of crown protection and interlocking root systems. However, individual trees receive little stimulation to develop stronger root systems, thus when they are released through thinnings, they are not as windfirm as they might be in other situations ${ }^{[18]}$. Additionally, site preparation processes during the establishment of plantations can influence root architecture and resistive anchorage of trees to windthrow and further make a stand susceptible to wind damage ${ }^{[75]}$. Further research following Hurricane Katrina found that stand spacing and tree height were more important in determining stem breakage in pine stands than in hardwood stands, suggesting that manipulating stand structure might act as a mitigation measure to prevent damage ${ }^{[99]}$.

The published research provides inconsistent results along these lines, however. In the southern U.S., Trousdell et al. ${ }^{[103]}$ found that the level of residual stocking or density in pine stands was not a factor with respect to tree damage. Therefore, they could not say that heavily thinned stands were more likely to be damaged than less-heavily thinned stands. In addition, after the passage of Hurricane Andrew (1992) two sites in the Florida Everglades were compared, one where $64 \%$ of pines (predominantly slash pine) were killed and another where only $14 \%$ of pines were killed. The variability of damage between the two sites was attributed to stand density and the one sustaining the higher damage levels was more densely stocked and homogenous in structure, whereas the other was less densely stocked ${ }^{[2]}$. In contrast to the impacts of wind storms on southern U.S. forests, research in Alaska found that forests more prone to storm damage included those with uneven-aged conditions and those containing smaller trees ${ }^{[45,65]}$. Highly susceptible stands were those that had higher tree densities, smaller stem sizes and areas that have a higher likelihood of past catastrophic canopy disturbance. Those stands that were least susceptible to wind damage were characterized by larger trees $(>88 \mathrm{~cm})$, old-growth characteristics and past small scale disturbances. These stands also had trees ranging across age classes. Moderately susceptible stands had few larger trees $(>88 \mathrm{~cm})$ and may have had one or more partial canopy disturbances. While windstorms from the Pacific Ocean do not generally grow to hurricane strength, the resulting impact on forests may be applicable to other regions ${ }^{[31]}$.

Preliminary reports following Hurricane Katrina (2005) highlighted the role of tree age as a contributing factor in damage predictions. Specifically, it was found that older trees are most susceptible to wind damage ${ }^{[107]}$, thus early indications are that stand age may be a good indicator of forest damage ${ }^{[66]}$. In De Soto National Forest in Mississippi, the majority of the damage occurred in upland longleaf pine forests with ages ranging between 11 and 30 years ${ }^{[107]}$. In contrast, Boutet and Weishampe ${ }^{[14]}$ found that older hardwoods sustained the most damage while young loblolly pine (Pinus taeda) stands sustained the least following Hurricane Fran (1996).

Often, soil conditions of an area prior to a storm are important in determining the overall level of tree damage. Soil conditions following Hurricane Fran (1996) were found to be a major contributing factor to overall tree damage. A roadside tree inventory used to determine the extent of hurricane damage showed more than 1,400 trees windthrown along $56 \mathrm{~km}$ of road, the bulk of which was attributed to saturated soils resulting 
from heavy rains followed by strong winds accompanying the hurricane ${ }^{[14]}$. However, these observations may have been biased by the fact that forests adjacent to open spaces and roads may be more susceptible to damage ${ }^{[27,99]}$. Another study ${ }^{[103]}$ investigated the impacts of Hurricane Donna (1960), a Category 2 storm that traveled through North Carolina and Virginia. In an eight county area close to the storm's path which received heavy rains prior to the arrival of the storm, it was determined that soil characteristics played an important role in assessing damage. Greater wind damage occurred on soils with restricted layers in the soil profile (i.e., clay). Half of the trees growing on these soils were damaged, while only $7 \%$ of trees growing on other soil types were damaged and greater wind damage was observed in trees growing on soils with moderately coarse texture as opposed to other types of soils.

The role of topography and aspect in forest damage associated with hurricanes is not as easily discernable and may be overshadowed by the influence of tree height, tree diameter, soil condition and dominant species type ${ }^{[16]}$. However, areas of increased exposure to damaging winds based on topographic characteristics may suggest more susceptibility to wind damage ${ }^{[12]}$. Bellingham $^{[8]}$ states that topographical aspect is important, given the increased levels of stem breakage and crown defoliation on slopes facing the path of a hurricane, as compared to those facing away from a hurricane. Conversely, Brokaw and Grear ${ }^{[15]}$ found that damage was equally applied to both north- and southfacing slopes during a hurricane over Puerto Rico ${ }^{[15]}$. Slight topographic variations may have been influential in determining tree damage in Congaree Swamp National Monument, South Carolina after the passage of Hurricane Hugo (1989). Within sloughs, approximately $19 \%$ of trees suffered serious damage and none of the dominant species (bald cypress [Taxodium distichum var. distichum], water tupelo [Nyssa aquatica]) were seriously damaged ${ }^{[90]}$. Trees within these sloughs may have been more sheltered from wind, however, the crowns of trees were as tall as or taller than trees in adjacent areas. At higher elevations in the Appalachian Mountains, wind damage associated with Hurricane Opal (1995) occurred amongst trees found in upper slope conditions and along ridges ${ }^{[21]}$. Further muddling the implied correlation between topographic characteristics and tree damage, Busby ${ }^{[18]}$ suggested that areas which suffer the most windthrow are those with flat or gently undulating terrain $^{[18]}$.

Ultimately, the characteristics of a forest (species composition, tree diameter, density and site conditions) are not independent of storm strength or location in determining a stand's damage susceptibility to damage.
For example, in the Santee Experimental Forest, South Carolina, Nix et al. ${ }^{[78]}$ found that there was no correlation between soil characteristics or stand conditions and damage levels after Hurricane Hugo (1989). Each of the damage-resistance features of stands had little effect on the destructiveness of high winds. However, in the nearby Francis Marion National Forest, stand condition explained nearly half of the variation in damage levels. This variability in damage between the two forests following the same storm is attributed to the proximity of the eye of the storm to each forest. In this instance, Santee Experimental Forest was closer to the eye of the storm, therefore, damage was inevitable regardless of the pre-storm stand characteristics.

Species-specific responses to hurricanes: Identifying species-specific responses to hurricanes is, unfortunately, difficult. Barry et al.$^{[5]}$ found that a tree's wind resistance is dependant on the strength of the wood, the shape and size of the crown, the extent and depth of the root system, soil moisture conditions and the shape of the tree bole. For example, in general, Stanturf et al. ${ }^{[99]}$ suggest greater losses in pine stands than in hardwood stands after Hurricane Katrina (2005), while the opposite was true following Hurricane Rita (2005). Following Hurricane Camille (1969), researchers found in one area of Mississippi that pines were damaged mainly by breaking, while hardwoods were damaged mainly by windthrow ${ }^{[55,104]}$. Damage varied across the affected area, indicating that wind intensity was inconsistent. Evidence following Hurricane Camille suggests that taller trees that were more likely to break than be windthrown ${ }^{[102]}$. Pines were more commonly broken, while hardwoods were more often windthrown ${ }^{[55,104]}$.

Conifers: Generally speaking, in the southern U.S., longleaf pine stands are typically more resilient to hurricane damage than loblolly pine stands and loblolly stands that have been recently thinned have an even higher likelihood of damage ${ }^{[58]}$. Within the Hobcaw Forest following Hurricane Hugo (1989), loblolly pine trees were most commonly broken or sustained crown damage, whereas only a small percentage $(5 \%)$ of longleaf pine were windthrown or broken during the storm. This finding was attributed to stands containing older longleaf pine trees ( $>70$ years), having low stocking levels and having been developed in open conditions for quite some time (providing a history of wind exposure $)^{[58]}$. Further investigation by Brokaw and Walker ${ }^{[6]}$ found that, in general, loblolly pine sustained more damage than hardwoods and baldcypress (Taxodium distichum var. distichum) and live oak sustained little damage. Gresham et $a l^{[52]}$ found that 
longleaf pine was the least damaged of the pines, however smaller longleaf pines sustained more damage than larger longleaf pine trees. Loblolly pine trees sustained moderate damage $(26 \%)$ and as a result of shallow rooting systems, pond pine (Pinus serotina) incurred the highest degree of damage (34\%).

Within the Florida Everglades Hurricane Donna (1960), over $90 \%$ of damage in thinned loblolly stands was from windthrow, not from stem breakage ${ }^{[103]}$. Surveys along fire roads estimated up to five windthrown pines per hectare while live oaks and slash pine were found windthrown at much lower frequencies. The increase in loblolly pine windthrow was a result of the type of bedrock present, which limited the root system development of loblolly pine trees $^{[27]}$.

Hardwoods and cypress swamps: In contrast to other storms, Glass and Oswalt ${ }^{[48]}$ found that hardwoods experienced more wind damage than softwoods and almost twice as much bole damage and windthrow following Hurricane Katrina (2005). As the distance inland increased of the hurricane, more hardwood damage was found than softwood damage. Bottomland hardwood sites included sycamore (Platanus occidentalis), ash (Fraxinus spp.) and elm (Ulmus spp.). Trees within approximately $20 \mathrm{~km}$ of the eye during Hurricane Katrina suffered the greatest amount of damage. These areas sustained approximately $60 \%$ tree loss due to windthrow. Cypress-tupelo stands sustained little damage, conversely, other bottomland hardwood stands lost close to a quarter of their stem density and basal area ${ }^{[32]}$. Hook et al ${ }^{[58]}$ described tree damage following Hurricane Hugo (1989) within the Santee Experimental Forest and Hobcaw Forest in South Carolina and found that oak species experienced the greatest amount of damage, which was attributed to the shallow rooting system and large crown architecture $^{[88]}$. Hook et al. ${ }^{[58]}$ found the bulk of heavy damage occurred in poorly drained bottomland hardwood depressions and hardwood-pine depressions. In another study south of the Hobcaw Forest in South Carolina after Hurricane Hugo, hardwoods (except swamp tupelo and live oak) suffered more wind damage than softwoods ${ }^{[51]}$. Live oak was an order of magnitude less damaged as compared to laurel oak (Quercus laurifolia) or water oak (Quercus nigra). Heavy damage occurred on approximately $19 \%$ of the laurel oak. Touliatos and $\operatorname{Roth}^{[102]}$ found similar damage patterns following Hurricane Camille (1969). Species such as baldcypress, live oak and pondcypress (Taxodium distichum var. nutans) were found to be more resilient to wind damage than other species. In general, live oaks are relatively wind resistant, with most damage arising through windthrow ${ }^{[34]}$.
Hardwoods within the Long Pine Key and Lostman's Pine areas of the Florida Everglades were found without canopies and foliage following Hurricane Andrew (1992). Approximately $85 \%$ of hammock trees were classified as heavily damaged with almost half of the damaged trees were windthrown. The underlying limestone bedrock and soils may have prevented some standing trees from being windthrown ${ }^{[2]}$. In another study, Pimm et al. ${ }^{[85]}$ found that most hardwoods were defoliated and approximately a quarter were broken, windthrown, or had broken limbs following Hurricane Andrew. During this storm, black willow (Salix nigra) trees were especially susceptible to windthrow ${ }^{[59]}$. Following Hurricane Andrew (1992), nearly 75\% of cypress that were located within approximately $20 \mathrm{~km}$ of the eye were damaged. Of the damaged cypress, $4 \%$ were heavily damaged (broken or windthrown) ${ }^{[2]}$. Noel et $a l .{ }^{[79]}$ surveyed cypress domes and found that cypress experienced little major damage when in close proximity to the hurricane eye wall and that breakage and other major damage occurred less frequently in smaller diameter trees. Additionally, levels of damage decreased more rapidly on the south (left) side of the hurricane track as one moved away from the eye, however the domes on the north (right) side of the hurricane track contained fewer broken trees. While height and diameter of trees were good predictors of damage, the size of the storm may affect the extent of area in which damage occurs, as well as the rate of decrease in damage as one moves away from the eye of the storm.

At higher elevations, a study ${ }^{50]}$ in response to Hurricane Opal (1995), which passed $240 \mathrm{~km}$ to the west of Bent Creek Experimental Forest in Asheville, North Carolina, examined the impact on predominantly hardwood forests. Surveys conducted within canopy gaps following the storm found that $17-38 \%$ of all live trees in the gaps were windthrown while $8-18 \%$ of the trees were broken. Windthrow most frequently occurred in red oaks (Quercus rubra), with scarlet oak (Quercus coccinea) comprising the majority (44-67\%) of windthrown trees when present ${ }^{[50]}$.

Storm surge damage: Storm surges precede the landfall of a hurricane and consist of a long wave of sea water in which the amplitude and frequency change continuously over time and space. In a non-dispersive condition, when more than one long wave is produced, subsequent waves can overtake the others and produce a single, steeper wave, of increased energy and amplitude ${ }^{[106]}$. Further, wind energy is converted to water momentum in front of the eye of a hurricane ${ }^{[63]}$. Storm surges generally occur with a peak wave along the right side of the storm track ${ }^{[56]}$. The worst case scenario is when the storm surge coincides with the 
astronomical high tide ${ }^{[62]}$. Most of the large human death tolls associated with hurricanes are the result of a storm surge greater than $3 \mathrm{~m}$ in height ${ }^{[10]}$. As an example of the magnitude of storm surges, an October 1898 hurricane that made landfall in Florida created a storm surge in Georgia that raised water levels $5.5 \mathrm{~m}$ above the mean high tide at Sapelo Lighthouse on Sapelo Island and $4 \mathrm{~m}$ above the mean high tide inland at the town of Darien, Georgia ${ }^{[4]}$. Hurricane Ivan (2004) made landfall as a Category 3 storm and Pensacola, Florida was in the northeast quadrant of the storm. Storm surges at Pensacola reached between 3 and $5 \mathrm{~m}$ high, raising water levels for $31 \mathrm{~h}$. The storm surge led to an increase in surface area of Pensacola Bay by approximately $50 \%$, corresponding to a $230 \%$ increase in water volume and affecting approximately $166 \mathrm{~km}^{2}$ of land ${ }^{[54]}$. Even more dramatic, Hurricane Katrina (2005) developed a storm surge of over $9 \mathrm{~m}$ in some coastal areas of Mississippi ${ }^{[44]}$.

Storm surges can result in severe forest damage due to increased salt levels resulting in increased levels of leaf and needle litterfall along with decreased levels of water uptake through roots ${ }^{[11]}$. Storm surges may not impact all areas of a forest equally: the spatial position of trees and the soil condition are important factors in determining the impact of saltwater inundation. Also, trees within closed depressions and areas beside drainages will be more heavily impacted and see higher mortality rates ${ }^{[46]}$. Further, wet weather prior to the hurricane may limit the ability of saltwater to infiltrate saturated soils ${ }^{[58]}$. Research following Hurricane Audrey (1957) found that trees most heavily impacted by high levels of salinity were located on fresh marsh soils and slowly permeable ridge soils. The least affected areas had highly permeable ridge soils. Rain facilitates the rapid permeability of these types of sandy soils ${ }^{[20]}$. Following the 1938 New England hurricane, Moss $^{[76]}$ observed that where surges occurred and water was impounded, all of the trees died. Gardner et al. ${ }^{[47]}$ found that the storm surge associated with Hurricane Hugo (1989) affected forests approximately $1.5 \mathrm{~km}$ inland. Low lying forest floors close to the coast held on to approximately $1 \mathrm{~m}$ of saltwater for nearly two weeks and then infiltrated the soil as the water table lowered again. As a result, soil salinity following the storm ranged from approximately $10-13 \mathrm{ppt}$ and peaked a week after the storm.

While baldcypress and some hardwoods have been found resistant to wind damage, past studies have found that these species may be more sensitive to salt inundation. Following Hurricane Hugo (1989), studies suggested that baldcypress and blackgum (Nyssa sylvatica var. sylvatica) were the most susceptible to damage from salinity, with stands of these tree species losing between 50 and $75 \%$ of their stocking due to salt inundation ${ }^{[22,46]}$. In stands that did not retain saltwater, almost a quarter of blackgum trees per unit area were damaged $^{[22]}$. Salinity within the surge areas either stressed or killed pines and the stressed pines eventually became a beetle infestation concern. Pine mortality typically occurred in forested areas adjacent to hardwood swales in topographic depressions ${ }^{[46]}$.

The impact of salinization in a forest may have more long term effects than the impact of wind damage ${ }^{[47]}$. The salinization effect on tree species varies $^{[24,2 \dot{6}]}$, however Barry et al. ${ }^{[6]}$ suggest that many affected trees may return to good health eventually. Nevertheless, storm surges have been identified as an important disturbance regime in maintaining some southeastern forest species, such as slash pine, by killing dense understory that may otherwise outcompete young pines trees for nutrients and sunlight $^{[100]}$. One additional issue facing land managers charged with forest damage recovery efforts concerns the appropriate amount of time to wait to plant trees in areas that were inundated with storm surge waters. The rate of movement of saltwater through the water table will ultimately depend on the rate of subsequent rainfall and the depth of the water table. With adequate rainfall, salt content will progressively decline in soils through leaching processes and maybe, within a year or two, eventually return to pre-hurricane levels ${ }^{[47,67]}$. Further complicating their role in hurricane damage, storm surges in combination with high winds may result in debris dams composed of tree, shrub, grass and aquatic vegetation. Windthrow composed of low-lying vegetation may combine with silt and peat to form debris dams which could potentially further trap saltwater in forest stands ${ }^{[23]}$.

Tree mortality levels: Inevitably, hurricanes will result in tree mortality. To better prepare, natural resource managers need to be able to gauge the degree to which tree mortality will occur following a hurricane. Factors that may influence a tree's susceptibility to mortality following a storm include tree species, diameter, stand condition and proximity to the storm's path. Brokaw and Walker ${ }^{[16]}$ suggested that while hurricanes can cause extensive structural damage, mortality rates may be surprisingly low. However, initial mortality estimates following a storm may be under-estimated, resulting from a lag time in species-specific mortality rates $^{[2]}$. For example, Sheffield and Thompson ${ }^{[96]}$ found that damaged hardwoods took longer to die than damaged pines. And Platt et al..$^{[86]}$ determined that mortality rates in slash pine were $17-25 \%$ shortly after Hurricane Andrew and 3-7\% a year later. Mortality rates were lower in old-growth stands and increased with increases in diameter. Armentano et al. ${ }^{[2]}$ found 
similar results following Hurricane Andrew (1992), where a predominantly old-growth forest sustained minor damage and had fewer instances of mortality following the storm. However, following Hurricane Kate (1985), Batista and Platt ${ }^{[7]}$ noted that overstory species had the greatest incidence of mortality. As we have noted earlier, the location of a stand of trees in relation to the radius of maximum sustained winds is important in determining tree damage and mortality levels. Research in Dade County Parks, Florida found that hardwood hammocks closest to the center of the eye of Hurricane Andrew suffered the highest tree mortality (67\%). The hardwood hammock approximately $8 \mathrm{~km}$ away from the edge of the eye had the least mortality $(32 \%)^{[59]}$.

Tree Regeneration: Micro-environments created by windthrow and subsequently exposed to high light levels will be quickly established by shade intolerant tree species following hurricanes ${ }^{[19]}$. In general, small canopy gaps may fill in quickly with existing canopy tree species following catastrophic wind disturbance, yet larger gaps rely on existing seed sources as well as introduced seeds for regeneration of trees ${ }^{[33]}$. The amount of debris on the ground is an issue, however. For example, the forest floor in hardwood hammocks following Hurricane Andrew (1992) was buried beneath a tremendous amount of dead vegetation, however, defoliated and damaged trees rapidly produced new shoots from suppressed buds on branches and boles. Accompanying the resprouting of hardwoods, exotic plant species also began to establish themselves. Natural regeneration of pine in small canopy gaps appears limited given the inadequate seed source and the capitalization of freed-up resources by hardwood tree species ${ }^{[2]}$. Putz and Sharitz ${ }^{[90]}$ found a decrease in species diversity due to the competitive nature of other species, such as maples (Acer spp.), that took advantage of post-storm conditions. In contrast, five years after Hurricane Fran (1996), one study ${ }^{[108]}$ suggested that there was little change in species composition following the disturbance. The storm essentially sped up the successional process in pine stands by increasing the dominance of understory hardwood species, which emphasizes the importance of multiple surveys a hurricane to determine the full extent of the change in tree species diversity brought about by the storm.

Dunn et $a l .{ }^{[33]}$ investigated the regeneration process of an old-growth hemlock-hardwood forest in New Hampshire following a catastrophic blowdown. The 1977 post-blowdown sample was compared to preblowdown datasets from 1967. Following the blowdown, approximately $6 \%$ of the basal area and $11 \%$ of the stems remained. After the downburst, yellow birch (Betula alleghaniensis), red maple (Acer rubrum) and basswood (Tilia americana) were the most common tree seedlings, with total seedling density increasing by approximately $100 \%$. Fifty-two percent of the seedlings were yellow birch. While hemlock (Tsuga canadensis) was a dominant species prior to the disturbance, hemlock seedlings were uncommon in the post-downburst forest.

The saltwater associated with a storm surge may also affect advanced regeneration. For example, red maple and red bay (Persea borbonia) seedlings are very sensitive to saltwater inundation and in one study, $80 \%$ of red maple seedlings died within two weeks of saltwater flooding. Three weeks after the flooding event, red bays began to die as a result of flooding. Unfortunately, neither tree species could handle more than one day of flooding ${ }^{[24]}$.

\section{DISCUSSION}

Immediate priorities following a hurricane are the safety and health of humans. Additionally, roads will need to be cleared, the safety of infrastructure such as bridges and power lines will need to be verified and all utilities will need to be restored ${ }^{[93]}$. These priorities, however, are not independent of the responsibility natural resource managers and landowners might feel in addressing the damage to their forests. Unfortunately, hurricane frequency, location and impact are difficult to predict. One step in making hurricane response plans easier to develop and implement is understanding how hurricanes impact forests and the biological and physical characteristics of a forest that may make them more susceptible to damage from a hurricane.

In addition to being prepared for potential damage to forests, natural resource managers and landowners should consider the management implications of hurricane damage recovery efforts. Many management decisions and planning efforts will be impacted by the directional fall of trees. Specifically, identifying potential areas of powerline damage, priority roads to be cleared and potential areas of fuel load accumulation will be of the utmost importance following a storm. Also, salvage logging operations will need to begin immediately following the storm. With this comes concern over protecting environmentally sensitive areas, as well as protecting residual stands of trees so that they will be both economically and ecologically viable after the storm. After Hurricane Opal (1995) struck the southern Appalachians, it was found that salvage logging promoted rapid understory regrowth and led to increases of tree density and basal area that were $5 \%$ greater than a site that had not been salvage logged. Stands consisted of various tree species including oaks, red maples, hickory (Carya spp.) and 
yellow-poplar. This effect was attributed to the pit and mound topography created by windthrow, combined with shade provided from remaining slash, which created the appropriate environmental conditions for increased species richness and diversity ${ }^{[36]}$. Similarly, Fail $^{[38]}$ made a comparison between regeneration in unsalvaged and salvaged plots conducted following Hurricane Hugo (1989) in a mixed loblolly pine/hardwood forest. Findings indicated that clearing of windthrown and damaged trees may have resulted in increased growth rates of surviving trees, along with higher levels of organic matter, greater decomposition rates and lower root:shoot ratios.

As we have alluded to, tree mortality that accompanies hurricane damage can also lead to an increased likelihood of insect outbreaks. Armentano et $a l .{ }^{[2]}$ observed, following Hurricane Andrew, that by the following spring, insect outbreaks accompanied pine mortality. Stressed vegetation can lead to infestations of insects such as engraver or bark beetles. Slash left behind following salvage operations can also provide an environment conducive to bark beetle outbreaks. These outbreaks can lead to beetle attacks on healthy trees if salvage operations are not timely ${ }^{[6]}$.

Natural resource managers will also need to consider the impact on wildlife following high winds and flooding associated with hurricanes. Wildlife species susceptibility has been correlated to a decrease in available habitat following hurricanes ${ }^{[17,61,85]}$ while others have attributed wildlife species susceptibility to changes in available food supply and microenvironments ${ }^{[101]}$. Following Hurricane Katrina (2005), damage in the DeSoto National Forest led to the loss of nearly half of the 150 red-cockaded woodpecker (Picoides borealis) cavity trees through breakage or windthrow of cavity trees ${ }^{[17]}$. Additionally, Hurricane Andrew (1992) damaged almost all of the red-cockaded woodpecker cavity trees in Everglades National Park, Big Cypress Reserve and Biscayne National Park ${ }^{[85]}$. On the Francis Marion National Forest alone, the majority (approx. 75\%) of the old-growth trees necessary for woodpecker habitat requirements were damaged $^{[61]}$. This loss of habitat for red-cockaded woodpeckers could lead to increased competition from other species for nesting habitat, forcing them to attempt to nest elsewhere, potentially leading to increased mortality from exposure or predation ${ }^{[37]}$.

High winds and flooding associated with hurricanes, particularly near the end of a growing season when plants have developed their seed, can also increase the opportunity for dispersal of exotic plants. Exotic plants can impact site diversity through competition with native plants. This, in turn, could potentially lead to the extinction of native flora ${ }^{[98]}$. Openings in tree canopies and opportunities for seed dispersal following a severe storm may accelerate the advancement of exotic species ${ }^{[68]}$.

\section{CONCLUSION}

Generalizations of the potential impacts of hurricanes on forests along the Atlantic Ocean and Gulf of Mexico coasts are difficult to develop. While forest responses vary based on geographic position in relation to the storm, stand characteristics, soils, species characteristics, topographic exposure and tree physiology are also important in assessing the risk to forest damage. For example, stand characteristics are important in determining potential damage since in general, those trees that are taller, larger and older have a higher likelihood of incurring direct damage than smaller, shorter and younger trees. Understory and midstory trees are more commonly damaged due to indirect means such as snapping and windthrow of adjacent trees, abrasion resulting from rubbing against neighboring trees and pinning by larger fallen canopy trees. Breakage or snapping in trees is more common in pine species, while hardwoods, in general, are more likely to be windthrown. Species such as baldcypress and live oak are fairly resistant to wind damage, likely a result of the morphological characteristics of these species. Windthrow is a function of multiple conditions, including soil type, soil moisture, short rooting systems and underlying bedrock. Tree taper has also been identified as an attribute that can help in identifying trees that may be damaged during a hurricane, suggesting that trees grown in crowded stands (such as plantations) approach cylindrical forms (low taper) making them more susceptible to damage. Stand density and structure play an important role in identifying higher risk areas, as less dense stands seem to be more resilient to wind damage. There were exceptions found following Hurricane Katrina (2005), with younger more densely spaced softwood stands having a lower degree of damage than hardwood stands ${ }^{[48]}$. Even-aged forest stands are generally most susceptible to damage from gusts while uneven-aged stands have shown a greater resilience. Additionally, any recent, significant change to the forest structure as a result of management practices may lead to stand susceptibility to wind damage ${ }^{[45]}$. Finally, trees adjacent to roads, open fields, or next to stands that were recently clearcut or heavily thinned are more susceptible to wind damage during a hurricane. The physical and biological responses need to be weighed against the economic and ecological risk landowners are willing to assume. Granted some management practices can be used to reduce risks and make stands of trees more wind-firm, however the cost and timing associated with these should be weighed against the uncertainty of hurricane events in a given region. 
Am. J. Environ. Sci., 5 (1): 16-32, 2009

\section{ACKNOWLEDGEMENT}

Funding for this research was provided by the Forestry Branch of Ft. Stewart, Georgia (USA), which is in the Environmental and Natural Resources Division of the Directorate of Public Works at the installation

\section{REFERENCES}

1. Anthes, R.A., 1982. Tropical cyclones, their evolution, structure and effects. Am. Meteorological Soc., Meteorological Monographs pp: 11-61. ISBN: 0933876548.

2. Armentano, T.V., R.F. Doren, W.J. Platt and T. Mullins, 1995. Effects of Hurricane Andrew on coastal and interior forests of southern Florida: overview and synthesis. J. Coastal Res., Special Issue, 21: 111-144.

3. Ayala-Silva, T. and Y.A. Twumasi, 2004. Hurricane Georges and vegetation change in Puerto Rico using AVHRR satellite data. Int. J. Remote Sensing, 25: 1629-1640. DOI: $10.1080 / 01431160310001595037$.

4. Barnes, J., 2007. Florida's hurricane history. 2nd Edn. The University of North Carolina Press, pp: 407. ISBN: 0807858099.

5. Barry, P.J., C. Doggett, R.L. Anderson and K.M. Swain, 1993. How to evaluate and manage storm-damaged forest areas. Manage. Bull. R8MB, $63:$ http://www.fs.fed.us/r8/foresthealth/pubs/storm_da mage/contents.html.

6. Barry, P.J., C. Doggett, R.L. Anderson and K.M. Swain, 1996. How to Evaluate and Manage Storm-Damaged Forest Areas. In: Hurricane Hugo: South Carolina Forest Land Research and Management Related to the Storm, Haymond, J.L. and W.R. Harms (Eds.). USDA Forest Service, Southern Research Station, Asheville, NC. General Technical Report SRS-5, pp: 28-33. http://www.srs.fs.usda.gov/pubs/gtr/gtr srs005.pdf

7. Batista, W.B. and W.J. Platt, 2003. Tree population responses to hurricane disturbance: Syndromes in a south-eastern USA old-growth forest. J. Ecol., 91: 197-212. DOI: $10.1046 /$ j.13652745.2003.00754.x.

8. Bellingham, P.J., 1991. Landforms influence patterns of hurricane damage: Evidence from Jamaican montane forests. Biotropica, 23: 427-433. http://www.jstor.org/stable/2388262.

9. Blackburn, P., J.A. Petty and K.F. Miller, 1988. An assessment of the static and dynamic factors involved in windthrow. Forestry, 61: 29-43. DOI: 10.1093/forestry/61.1.29.
10. Blake, E.S., E.N. Rappaport and C.W. Landsea, 2007. The deadliest, costliest and most intense United States tropical cyclones from 1851 to 2006 (and other frequently requested hurricane facts). U.S. Department of Commerce, National Weather Service, National Hurricane Center, Miami, FL. NOAA Technical Memorandum NWS TPC-5 pp. 43.

http://www.aoml.noaa.gov/hrd/Landsea/Blakeetal noaamemoApr2007.pdf

11. Blood, E.R., P. Anderson, P.A. Smith, C. Nybro and K.A. Ginsberg, 1991. Effects of Hurricane Hugo on coastal soil solution chemistry in South Carolina. Biotropica, 23: 348-355. http://www.jstro.org/stable/2388251.

12. Boose, E.R., D.R. Foster and M. Fluet, 1994. Hurricane impacts to tropical temperate forest landscapes. Ecol. Monographs, 64: 370-400. DOI: $10.2307 / 2937142$

13. Boucher, D.H., C.L. Rodick, J.N. Bailey, J.L. Snitzer, K.L. Kyde and B. Prudden, 2005. Hurricane Isabel and the Forests of the MidAtlantic Piedmont and Blue Ridge: Short-Term Impacts and Long-Term Projections. In: Hurricane Isabel in Perspective Sellner, K.G. (Ed.). Chesapeake Research Consortium, Edgewater, MD. CRC Publication 05-160, pp: 201-208. http://www.chesapeake.org/pubs/Isabel/Boucher\% 20et\%20al.pdf.

14. Boutet, J.C. and J.F. Weishampel, 2003. Spatial pattern analysis of pre- and post- hurricane forest canopy structure in North Carolina, USA. Landscape Ecol., 18: 553-559. DOI: 10.1023/A:1026058312853.

15. Brokaw, N.V.L. and J.S. Grear, 1991. Forest structure before and after Hurricane Hugo at three elevations in the Luquillo Mountains, Puerto Rico. Biotropica, 23: 386-392. http://www.jstor.org/stable/2388256.

16. Brokaw, N.V.L. and L.R. Walker, 1991. Summary of the effects of Caribbean hurricanes on vegetation. Biotropica, 23: 442-447. http://www.jstor.org/stable/2388264.

17. Bryant, D. and J. Boykin, 2007. Fuels Management on the National Forests in Mississippi after Hurricane Katrina. In: The Fire EnvironmentInnovations, Management and Policy, Butler, B.W. and W. Cook (Eds.). Proceedings RMRS-P-46CD. Fort Collins, CO: U.S. Department of Agriculture, Forest Service, Rocky Mountain Research Station, pp: 287-292. http://www.fs.fed.us/rm/pubs/rmrs_p046/rmrs_p04 6_287_292.pdf

18. Busby, J.A., 1965. Studies on the stability of conifer stands. Scottish For., 19: 86-102. 
19. Carlton, G.C. and F.A. Bazzaz, 1998. Resource congruence and forest regeneration following an experimental hurricane blowdown. Ecology, 79: 1305-1319. http://ejournals.ebsco.com/direct.asp?ArticleID $=4 \mathrm{C}$ CE853FDD0423AE57B9.

20. Clark, H.L. and R.L. Juve, 1962. Effects of saline water from Hurricane Audrey on soils. Agron. J., 54: 390-392. http://agron.scijournals.org/cgi/reprint/54/5/390.

21. Clinton, B.D. and C.R. Baker, 2000. Catastrophic windthrow in the southern Appalachians: Characteristics of pits and mounds and initial vegetation responses. For. Ecol. Manage., 126: 51-60. DOI: 10.1016/S0378-1127(99)000821.

22. Conner, W.H., 1995. Woody plant regeneration in three South Carolina Taxodium/Nyssa stands following Hurricane Hugo. Ecol. Eng., 4: 277-287. DOI: 10.1016/0925-8574(94)00054-9.

23. Conner, W.H., 1996. Impact of Hurricanes on Forests of the Atlantic and Gulf Coasts. In: Hurricane Hugo: South Carolina Forest Land Research and Management Related to the Storm (eds J.L. Haymond and W.R. Harms). USDA Forest Service, Southern Research Station, Asheville, NC. General Technical Report SRS-5, pp: 6-12. http://www.srs.fs.usda.gov/pubs/gtr/gtr_srs005.pdf

24. Conner, W.H. and G.R. Askew, 1993. Impact of saltwater flooding on red maple, redbay and Chinese tallow seedlings. Castanea, 58: 214-219. http://www.jstor.org/stable/4033645.

25. Conner, W.H., J.W. Day, Jr., R.H. Baumann and J.M. Randall, 1989. Influence of hurricanes on coastal ecosystems along the northern Gulf of Mexico. Wetlands Ecol. Manage., 1: 45-56. DOI: 10.1007/BF00177889.

26. Conner, W.H., K.W. McLeod and J.K. McCarron, 1997. Flooding and salinity effects on growth and survival of four common forested wetlands species. Wetlands Ecol. Manage., 5: 99-109. DOI: 10.1023/A:1008251127131.

27. Craighead, F.C. and V.C. Gilbert, 1962. The effects of Hurricane Donna on the vegetation of southern Florida. Q. J. Florida Acad. Sci., 25: 1-28. http://www.floridaacademyofsciences.org/flsci.htm

28. Cremer, K.W., C.J. Borough, F.H. McKinnell and P.R. Carter, 1982. Effects of stocking and thinning on wind damage in plantations. N.Z. J. For. Sci., 12: 244-268. http://nzjfs.scionresearch.com/Corp/KC/NZJFSSub s.nsf?OpenDatabase
29. Croker, T.C., Jr., 1958. Soil depth affects windfirmness of longleaf pine. J. For., 56: 432. http://saf.publisher.ingentaconnect.com/content/saf /jof/1958/00000056/00000006/art00013.

30. Curtis, J.D., 1943. Some observations on wind damage. J. For., 41: 877-882. http://saf.publisher.ingentaconnect.com/content/saf /jof/1943/00000041/00000012/art00007.

31. DeGayner, E.J., M.G. Kramer, J.G. Doerr and M.J. Robertsen, 2005. Windstorm disturbance effects on forest structure and black bear dens in southeast Alaska. Ecol. Appl., 15: 1306-1316. http://ejournals.ebsco.com/direct.asp?ArticleID $=47$ 2EAE676034B193BE59.

32. Doyle, T.W., B.D. Leeland, L.E. Gorham and D.J. Johnson, 1995. Structural impact of Hurricane Andrew on the forested wetlands of the Atchafalaya basin in south Louisiana. J. Coastal Res., 21: 354-364. http://www.jcronline.org/perlserv/?request=indexhtml

33. Dunn, C.P., G.R. Guntenspergen and J. Dorney, 1983. Catastrophic wind disturbance in an oldgrowth hemlock-hardwood forest, Wisconsin. Can. J. Botany, 61: 211-217. DOI: 10.1139/b83-204.

34. Duryea, M.L., 1997. Wind and trees: Surveys of tree damage in the Florida panhandle after Hurricanes Erin and Opal. School of Forest Resources and Conservation, Florida Cooperative Extension Service, Institute of Food and Agricultural Sciences, University of Florida, Gainesville, FL. Circular 1183, pp: 1-8. http://edis.ifas.ufl.edu/pdffiles/FR/FR01000.pdf .

35. Duryea, M.L., G.M. Blakeslee, W.G. Hubbard and R.A. Vasquez, 1996. Winds and trees: A survey of homeowners after Hurricane Andrew. J. Arboriculture, 22: 44-50. http://www.treelink.org/joa/

36. Elliot, K.J., S.L. Hitchcock and L. Krueger, 2002. Vegetation response to large scale disturbance in a southern Appalachian forest: Hurricane Opal and salvage logging. J. Torrey Botanical Soc., 129: 48-59. http://www.jstor.org/stable/3088682.

37. Engstrom, R.T. and G.W. Evans, 1990. Hurricane damage to Red-cockaded Woodpecker (Picoides borealis) cavity trees. The Auk, 107: 608-610. http://www.jstor.org/stable/4087930.

38. Fail, J., 1999. Production and decomposition rates of a coastal plain forest following the impact of Hurricane Hugo. J. Elisha Mitchell Sci. Soc., 115: 47-54. http://www.srs.fs.usda.gov/pubs/ja/ja_fail001.pdf. 
39. Finnigan, J.J. and Y. Brunet, 1995. Turbulent Airflow in Forests on Flat and Hilly Terrain. In: Wind and Trees, Coutts, M.P. and J. Grace (Eds.). Cambridge University Press, Cambridge, U.K, pp: 3-40. ISBN: 0521460379.

40. Foster, D.R. and E.R. Boose, 1992. Patterns of forest damage resulting from catastrophic wind in central New England, USA. J. Ecol., 80: 79-98. http://search.ebscohost.com/login.aspx?direct=true $\& \mathrm{db}=\mathrm{a} 9 \mathrm{~h} \& \mathrm{AN}=13949585 \&$ site $=$ ehost-live.

41. Foster D.R. and E.R. Boose, 1995. Hurricane Disturbance Regimes in Temperate and Tropical Forest Ecosystems. In: Wind and Trees, Coutts, M.P. and J. Grace (Eds.). Cambridge University Press, Cambridge, U.K. pp: 305-339. ISBN: 0521460379.

42. Foster, D.R., D.H. Knight and J.F. Franklin, 1998. Landscape patterns and legacies resulting from large, infrequent forest disturbances. Ecosystems, 1: 497-510. DOI: 10.1007/s100219900046.

43. Fraser, A.I., 1962. The soil and roots as factors in tree stability. Scottish Forestry, 18: 84-92. DOI: 10.1093/forestry/35.2.117.

44. Fritz, H.M., C. Blount, R. Sokoloski, J. Singleton, A. Fuggle, B.G. McAdoo, A. Moore, C. Grass and B. Tate, 2007. Hurricane Katrina storm surge distribution and field observations on the Mississippi Barrier Island. Estuarine, Coastal Shelf Sci., 74: 12-20. DOI: 10.1016/j.ecss.2007.03.015.

45. Gardiner, B.A., 1995. The Interactions of Wind and Tree Movement in Forest Canopies. In: Wind and Trees, Coutts, M.P. and J. Grace (Eds.). Cambridge University Press, Cambridge, U.K. pp: 41-59. ISBN: 0521460379.

46. Gardner, L.R., W.K. Michener, T.M. Williams, E.R. Blood, B. Kjerve, L.A. Smock, D.J. Lipscomb and C. Gresham, 1992. Disturbance effects of Hurricane Hugo on a pristine coastal landscape: North Inlet, South Carolina. Neth. J. Sea Res., 30: 249-263. DOI: 10.1016/0077-7579(92)90063$\mathrm{K}$

47. Gardner, L.R., W.K. Michener, T.M. Williams, E.R. Blood, B. Kjerve, L.A. Smock, D.J. Lipscomb and C. Gresham, 1996. Disturbance Effects of Hurricane Hugo on a Pristine Coastal Landscape: North Inlet, South Carolina. In: Hurricane Hugo: South Carolina Forest Land Research and Management Related to the Storm, Haymond, J.L. and W.R. Harms (Eds.). USDA Forest Service, Southern Research Station, Asheville, NC. General Technical Report SRS-5, pp: 226-243. http://www.srs.fs.usda.gov/pubs/gtr/gtr_srs005.pdf
48. Glass, P.A. and S.N. Oswalt, 2007. Initial estimates of Hurricane Katrina impacts on Mississippi Gulf Coast forest resources. Mississippi Institute for Forest Inventory, Mississippi Forestry Commission, Jackson, MS. 4p. http://www.mfc.state.ms.us/pdf/MIFI/Katrin_Impa cts_Gulf_Coast.pdf.

49. Goldenbērg, S.B., C.W. Landsea, A.M. MestasNunez and W.M. Gray, 2001. The recent increase in Atlantic hurricane activity: Causes and implications. Science, 293: 474-479. DOI: 10.1126/science. 1060040 .

50. Greenberg, C.H. and W.H. McNab, 1998. Forest disturbance in hurricane-related downbursts in the Appalachian mountains of North Carolina. For. Ecol. Manage., 104: 179-191. DOI: 10.1016/S0378-1127(97)00246-6.

51. Gresham, C.A., T.M. Williams and D.J. Lipscomb, 1991. Hurricane Hugo wind damage to southeastern U.S. coastal forest tree species. Biotropica, 23: 420-426. http://www.jstor.org/stable/2388261.

52. Gresham, C.A., T.M. Williams and D.J. Lipscomb, 1996. Hurricane Hugo Damage Assessment of Bottomland Hardwoods in South Carolina. In: Hurricane Hugo: South Carolina Forest Land Research and Management Related to the Storm, Haymond, J.L. and W.R. Harms (Eds.). USDA Forest Service, Southern Research Station, Asheville, NC. General Technical Report SRS-5, pp: 64-71. http://www.srs.fs.usda.gov/pubs/gtr/gtr_srs005.pdf

53. Grisez, T.J., 1954. Hurricane damage on Penobscot Experimental Forest. Forest Research Note NE-39. Upper Darby, P.A. U.S. Department of Agriculture, Forest Service, Northeastern Forest Experiment Station, 2p. http://nrs.fs.fed.us/pubs/rn/frn_ne39.pdf.

54. Hagy, J.D. III., J.C. Lehter and M.C. Murrell, 2006. Effects of Hurricane Ivan on water quality in Pensacola Bay, Florida. Estuaries Coasts, 29: 919-925. DOI: 10.1007/BF02798651.

55. Hedlund, A., 1969. Hurricane Camille's impact on Mississippi Timber. Southern Lumberman, 219: 191-192. http://southernlumberman.com/Content/Toc.aspx

56. Ho, F.P. and J.F. Miller, 1982. Pertinent meteorological and hurricane tide data for Hurricane Carla. U.S. Department of Commerce, National Oceanic and Atmospheric Administration, National Weather Service, Silver Spring, MD. NOAA Technical Report NWS 32, 111p. http://www.csc.noaa.gov/hes/images/pdf/HURR_C ARLA_MET_TIDE_DATA.pdf. 
57. Ho, F.P. and J.F. Miller, 1983. Pertinent meteorological data for hurricane Allen of 1980. U.S. Department of Commerce, National Oceanic and Atmospheric Administration, Silver Spring, MD. NOAA Technical Report NWS 35, 73p. http://www.csc.noaa.gov/hes/images/pdf/HURR_A LLEN80_MET_DATA.pdf.

58. Hook, D.D., M.A. Buford and T.W. Williams, 1996. Impact of Hurricane Hugo on the South Carolina Coastal Plain Forest. In: Hurricane Hugo: South Carolina Forest Land Research and Management Related to the Storm, Haymond, J.L. and W.R. Harms (Eds.). USDA Forest Service, Southern Research Station, Asheville, NC. General Technical Report SRS-5, pp: 34-43. http://www.srs.fs.usda.gov/pubs/gtr/gtr_srs005.pdf

59. Horvitz, C.C., S. McMann and A. Freeman, 1995. Exotics and hurricane damage in three hardwood hammocks in Dade County Parks, Florida. J. Coastal Res., 21: 145-158. http://www.jcronline.org/perlserv/?request=indexhtml.

60. Jacobs, M.R., 1936. The effect of winds on trees. Aust. $\quad$ For., 1: 25-32. http://www.forestry.org.au/ifa/c/c2-ifa.asp.

61. Janiskee, R.L., 1990. Storm of the Century: Hurricane Hugo and its impact on South Carolina. Southeastern Geographer, 30: 63-67. http://www.geography.vt.edu/sedaag/.

62. Jarvinen, B. and J. Gebert, 1986. Comparison of observed versus SLOSH model computed storm surge hydrographs along the Delaware and New Jersey shorelines for hurricane Gloria, September 1985. U.S. Department of Commerce, National Hurricane Center, Coral Gables, FL. NOAA Technical Memorandum NWS NHC 32, 17p.. http://www.aoml.noaa.gov/general/lib/lib1/nhclib/n wstechmemos/techmemo32.pdf.

63. Jarvinen, B. and J. Gebert, 1987. Observed versus SLOSH model storm surge for Connecticut, New York and upper New Jersey in hurricane Gloria, September 1985. U.S. Department of Commerce, National Hurricane Center, Coral Gables, FL. NOAA Technical Memorandum NWS NHC 36, 17p. http://www.nhc.noaa.gov/pdf/NWS-NHC1987-36.pdf

64. Jordan, C.L., D.A. Hurt and C.A. Lowrey, 1960. On the structure of Hurricane Daisy on 27 August 1958. J. Meteorol., 17: 337-348. DOI: $10.1175 / 1520$ 0469(1960)017<0337:OTSOHD>2.0.CO;2.

65. Kramer, M.G., A.J. Hansen, M.L. Taper and E.J. Kissinger, 2001. Abiotic controls on long-term windthrow disturbance and temperate rain forest dynamics in southeast Alaska. Ecology, 82: 2749-2768. http://ejournals.ebsco.com/direct.asp?ArticleID $=46$ DF81C694760EF5101D.
66. Kupfer, J.A., A.T. Myers, S.E. McLane and G.N. Melton, 2008. Patterns of forest damage in a southern Mississippi landscape caused by Hurricane Katrina. Ecosystems, 11: 45-60. DOI: 10.1007/s10021-007-9106-z.

67. Little, S., J.J. Mohr and L.L. Spicer, 1958. Saltwater storm damage to loblolly pine forests. J. For., 56: 27-28. http://saf.publisher.ingentaconnect.com/content/saf /jof/1958/00000056/00000001/art00009.

68. Loope, L., M. Duever, A. Herndon, J. Snyder and D. Jansen, 1994. Hurricane impact on uplands and freshwater swamp forest. BioScience, 44: 238-246. http://www.jstor.org/stable/1312228.

69. Lugo, A.E., M. Applefield, D.J. Pool and R.B. McDonald, 1983. The impact of Hurricane David on the forests of Dominica. Can. J. For. Res., 13: 201-211. DOI: 10.1139/x83-029.

70. Mallin, M.A., M.H. Posey, M.R. McIver, D.C. Parsons, S.H. Ensign and T.D. Alphin, 2002. Impacts and recovery from multiple hurricanes in a Piedmont - Coastal plain River system. Bioscience, 52: 999-1010 http://www.ingentaconnect.com/content/aibs/bio/2 002/00000052/00000011/art00007?crawler=true.

71. Marion, D.A. and K. Leftwhich, 2005. Recommendations for controlling stream impacts following Hurricane Katrina on De Soto National Forest. Supporting Documentation for Katrina Recovery Project Environmental Assessment. National Forests in Mississippi, Jackson, M.S. htt://www.fs.fed.us/r8/Mississippi/Katrina/EA/Sup porting_Documentation/Controlling_Stream_Impa cts_Report.pdf, May 9, 2008.

72. Mayer, H., 1987. Wind-induced tree sways. Trees, 1: 195-206. DOI: 10.1007/BF01816816.

73. Mayfield, M., L. Avila and E.D. Rappaport, 1994. Atlantic Hurricane season of 1992. Monthly Weather Rev., 122: 517-538. DOI: 10.1175/15200493(1994)122<0517:AHSO>2.0.CO;2.

74. Mergen, F., 1954. Mechanical aspects of windbreakage and windfirmness. J. For., 52: 119-125. http://saf.publisher.ingentaconnect.com/content/saf /jof/1954/00000052/00000002/art00009.

75. Miller, K.F., 1986. Windthrow hazard in conifer plantations. Irish For., 43: 66-78. http://www.societyofirishforesters.ie/completeliste ntrypage.htm.

76. Moss, A.E., 1940. Effect on trees of wind-driven saltwater. J. For., 38: 421-425. http://www.ingentaconnect.com/saf/jof/1940/0000 0038/00000005/art00014.

77. Nelson, T.C. and G.W. Stanley, 1959. Hurricane damage related to thinning intensity in east Texas slash pine plantations. J. For., 57: 39. http://saf.publisher.ingentaconnect.com/content/saf /jof/1959/00000057/00000001/art00014. 
78. Nix, L.E., D.D. Hook, J.G. Williams and D. van Blaricom, 1996. Assessment of Hurricane Damage to the Santee Experimental Forest and the Francis Marion National Forest with a geographic Information System. In: Hurricane Hugo: South Carolina Forest Land Research and Management Related to the Storm, Haymond, J.L. and W.R. Harms (Eds.). USDA Forest Service, Southern Research Station, Asheville, NC. General Technical Report SRS-5, pp: 44-51. http://www.srs.fs.usda.gov/pubs/gtr/gtr_srs005.pdf

79. Noel, J.M., A. Maxwell, W.J. Platt and L. Pace, 1995. Effects of Hurricane Andrew on cypress (Taxodium distichum var. nutans) in South Florida. J. Coastal Res., 21: 184-196. http://www.jcronline.org/perlserv/?request=indexhtml.

80. Orton, R., 1970. Tornadoes associated with hurricane Beulah on September 19-23, 1967. Monthly Weather Review, 98: 541-547. http://docs.lib.noaa.gov/rescue/mwr/098/mwr-09807-0541.pdf.

81. Parresol, B.R. and S. Alemañy, 1998. Analysis of tree damage from hurricane Hugo in the Caribbean National Forest, Puerto Rico. Proceedings of the 9th Biennial Southern Silvicultural Research Conference USDA Forest Service, Southern Research Station, Asheville, NC. General Technical Report SRS-20, pp: 599-603. http://www.srs.fs.usda.gov/pubs/gtr/gtr_srs020/CH 17.PDF.

82. Pearson, A.D. and F. Sadowski, 1965. Hurricaneinduced tornadoes and their distribution. Monthly Weather Rev., 93: 461-464. DOI: 10.1175/15200493(1965)093<0461:HITATD>2.3.CO;2.

83. Peart, D.R., C.V. Cogbill and P.A. Palmiotto, 1992. Effects of logging history and hurricane damage on canopy structure in a northern hardwoods forest. Bull. Torrey Botanical Club, 119: 29-38. http://www.jstor.org/stable/2996917.

84. Petty, J.A. and C. Swain, 1985. Factors influencing stem breakage of conifers in high winds. Forestry, 58: 75-84. DOI: 10.1093/forestry/58.1.75.

85. Pimm, S.L., G.E. Davis, L. Loope, C.T. Roman, T.J. Smith III and J.T. Tilmant, 1994. Hurricane Andrew. BioScience, 44: 224-229. http://search.ebscohost.com/login.aspx?direct=true $\& \mathrm{db}=\mathrm{a} 9 \mathrm{~h} \& \mathrm{AN}=9405192441 \&$ site $=$ ehost-live.

86. Platt, W.J., R.F. Doren and T.V. Armentano, 2000. Effects of Hurricane Andrew on stands of slash pine (Pinus elliottii var. densa) in the Everglades region of south Florida (USA). Plant Ecol., 146: 43-60. http:/www.ingentaconnect.com/klu/vege/2000/000 00146/00000001/00243943.
87. Powell, M.D., 1982. The transition of the Hurricane Frederic boundary-layer wind field from the open Gulf of Mexico to landfall. Monthly Weather Rev., 110: 1912-1932. DOI: $10.1175 / 1520$ 0493(1982)110<1912:TTOTHF $>2.0 . \mathrm{CO} ; 2$.

88. Purvis, J.C., 1996. History of Damaging Storms Affecting South Carolina Forests Including a Review of Hurricane Hugo's Impact on South Carolina's Forests. In: Hurricane Hugo: South Carolina Forest Land Research and Management Related to the Storm, Haymond, J.L. and W.R. Harms). USDA Forest Service, Southern Research Station, Asheville, NC. General Technical Report SRS-5, pp: 2-5. http://www.srs.fs.usda.gov/pubs/gtr/gtr_srs005.pdf

89. Putz, F.E., P.D. Coley, K. Lu, A. Montalvo and A. Aiello, 1983. Uprooting and snapping of trees: Structural determinants and ecological consequences. Can. J. For. Res., 13: 1011-1020. DOI: $10.1139 / \mathrm{x} 83-133$.

90. Putz, F.E. and R.R. Sharitz, 1991. Hurricane damage to old-growth forest in Congaree Swamp National Monument, South Carolina, USA. Can. J. For. Res., 21: 1765-1770. DOI: 10.1136/x91-244.

91. Ramsey, E.W. III, M.E. Hodgson, S.K. Sapkota and G.A. Nelson, 2001. Forest impact estimated with NOAA AVHRR and Landsat TM data related to an empirical hurricane wind-field distribution. Remote Sensing Environ., 77: 279-292. DOI: 10.1016/S0034-4257(01)00217-6.

92. Rappaport, E.N. and C.J. McAdie, 1991. Hurricane Gilbert (1988) in review and perspective. U.S. Department of Commerce, National Oceanic and Atmospheric Administration, National Weather Service, Coral Gables, FL. NOAA Technical Memorandum NWS NHC-45, 91p. http://www.aoml.noaa.gov/general/lib/lib1/nhclib/n wstechmemos/techmemo45.pdf.

93. Reinhart, D.R. and P.T. McCreanor, 1999. Disaster debris management-Planning tools. Final report submitted to the U.S. Environmental Protection Agency, Region IV. University of Central Florida, Orlando, FL., 33p.

94. Ross, M.S., M. Carrington, L.J. Flynn and P.L. Ruiz, 2001. Forest succession in tropical hardwood hammocks of the Florida Keys: effects of direct mortality from Hurricane Andrew. Biotropica, 33: 22-33. http://www.jstor.org/stable/2663762.

95. Schaetzl, R.J., D.L. Johnson, S.F. Burns and T.W. Small, 1989. Tree uprooting: Review of terminology, process and environmental implications. Can. J. For. Res., 19: 1-11. DOI: 10.1139/x89-001. 
96. Sheffield, R.M. and M.T. Thompson, 1996. Hurricane Hugo: Effects on South Carolina's Forest Resource. In: Hurricane Hugo: South Carolina Forest Land Research and Management Related to the Storm, Haymond, J.L. and W.R. Harms (Eds.). USDA Forest Service, Southern Research Station, Asheville, NC. General Technical Report SRS-5, pp: 122-159. http://www.srs.fs.usda.gov/pubs/gtr/gtr_srs005.pdf

97. Slater, H.H., W.J. Platt, D.B. Baker and H.A. Johnson, 1995. Effects of Hurricane Andrew on damage and mortality of trees in subtropical hardwood hammocks of Long Pine Key, Everglades National Park, Florida, USA. J. Coastal Res., 21: 197-207. http://www.jcronline.org/perlserv/?request=indexhtml.

98. Snitzer, J.L., D.H. Boucher and K.L. Kyde, 2005. Response of Exotic Invasive Plant Species to Forest Damage Caused by Hurricane Isabel. In: Hurricane Isabel in Perspective, K.G. Sellner (Ed.). Chesapeake Research Consortium, Edgewater, MD. CRC Publication 05-160, pp: 209-214. http://www.chesapeake.org/pubs/Isabel/Boucher\% 20et\%20al.pdf

99. Stanturf, J.A, S.L. Goodrick and K.W. Outcalt, 2007. Disturbance and coastal forests: A strategic approach to forest management in hurricane impact zones. For. Ecol. Manage., 250: 119-135. DOI: 10.1016/j.foreco.2007.03.015.

100.Stoneburner, D.L., 1978. Evidence of hurricane influence on barrier island slash pine forests in the northern Gulf of Mexico. Am. Midland Naturalist, $\quad$ 99: 234-237. http://www.jstor.org/stable/2424946.

101.Tanner, E.V.J., V. Kapos and J.R. Healey, 1991. Hurricane effects on forest ecosystems in the Caribbean. Biotropica, 23: 513-521. http://www.jstor.org/stable/2388274.
102. Touliatos, P. and E. Roth, 1971. Hurricanes and trees: Ten lessons from Camille. J. For., 69: 285-289. http://saf.publisher.ingentaconnect.com/content/saf /jof/1971/00000069/00000005/art00012.

103.Trousdell, K.B., W.C. Williams and T.C. Nelson, 1965. Damage to recently thinned loblolly pine stands. J. For., 63: 96-100. http://saf.publisher.ingentaconnect.com/content/saf /jof/1965/00000063/00000002/art00006.

104. Van Hooser, D.D. and A. Hedlund, 1969. Timber damaged by Hurricane Camille in Mississippi. U.S. Department of Agriculture, Forest Service, Southern Forest Experiment Station, New Orleans, LA. Research Note SO-96, 5p.

105. Wakimoto, R.M. and P.G. Black, 1994. Damage survey of hurricane Andrew and its relationship to the eyewall. Bull. Am. Meteorol. Soc., 75: 189-200. DOI: 10.1175/15200477(1994)075<0189:DSOHAA>2.0.CO;2.

106. Wang, H., J. Cho, J. Shen and Y.P. Wang, 2005. What has been Learned about Storm Surge Dynamics from Hurricane Isabel Model Simulation? In: Hurricane Isabel in Perspective, Sellner, K.G. (Ed.). Chesapeake Research Consortium, Edgewater, MD. CRC Publication 05160, pp: 117-125. http://www.chesapeake.org/pubs/Isabel/Boucher\% 20et $\% 20$ al.pdf

107.Windham, J.W., 2005. Forest vegetation analysis, Hurricane Katrina damaged tree removal and hazardous fuels. http://www.fs.fed.us/r8/ mississippi/katrina/EA/Supporting_Documentation /Katrina_Forest_Vegetation_Analysis.pdf February 25,2008 .

108.Xi, W., R.K. Peet and D.L. Urban, 2008. Changes in forest structure, species diversity and spatial pattern following hurricane disturbance in a Piedmont North Carolina forest, USA. J. Plant Ecol., 1: 43-57. DOI: 10.1093/jpe/rtm003. 